\title{
The Application of the Cabotage Principle in Shipping Transportation to Support Indonesia to Become a World Maritime Axis
}

\author{
Aflah $^{1}$, Hasim Purba $^{2}$, Suhaidi ${ }^{3}$, Mahmul Siregar ${ }^{4}$ \\ ${ }^{1}$ Universitas Sumatera Utara, Medan - Indonesia \\ ${ }^{2}$ Universitas Sumatera Utara, Medan - Indonesia \\ ${ }^{3}$ Universitas Sumatera Utara, Medan - Indonesia \\ ${ }^{4}$ Universitas Sumatera Utara, Medan - Indonesia \\ Email: aflah@usu.ac.id
}

\begin{abstract}
Indonesia is designated as an archipelagic country as well as a maritime country by the United Nations Convention on the Law of the Sea (UNCLOS) 1982. The current government aspires to make Indonesia the world's maritime axis country as outlined in Act No. 17 of 2005 concerning the Long-term National Development Plan 2005-2025, which emphasizes that within 20 years of implementation of development in Indonesia, one of them is aimed at realizing the strength and independence of Indonesia as an archipelagic country. The strengthening and independence of Indonesia as an archipelagic country was carried out by the Government by issuing Presidential Instruction No. 5 of 2005 concerning the Empowerment of the National Shipping Industry which regulates the consequent application of the Cabotage principle in shipping transportation to safeguard the sovereignty of the Indonesian sea territory. The application of the Cabotage principle supports the growth of the national shipping industry to realize Indonesia as a world maritime axis further regulated in Act No. 17 of 2008 concerning Shipping and Act No. 32 of 2014 concerning Marine. The research method in this journal is done by studying literature and supported by some empirical data.
\end{abstract}

Keywords: Cabotage Principle, Shipping Transportation, Maritime Axis.

\section{INTRODUCTION}

Indonesia's position as the largest archipelagic country in the world with 17,499 islands with a total area of about 7.81 million $\mathrm{km} 2$. Of the total area, 3.25 million $\mathrm{km}^{2}$ is oceans and 2.55 million $\mathrm{km} 2$ is the Exclusive Economic Zone. Only about 2.01 million $\mathrm{km}^{2}$ as land.[1] This condition makes sea transportation a vital business activity for the national economy. In this context, sea transportation services are not only important for the national economy but also in the effort to unite the islands in Indonesia to maintain the territorial integrity of the Unitary State of the Republic of Indonesia.

The declaration of The United Nations Convention on the Law of the Sea (UNCLOS) III in 1982 confirmed Indonesia as an archipelagic country. This convention has been ratified by 140 countries. Indonesia has ratified this Convention and further stipulated in Act Number 17 of 1985 concerning Ratification of the United Nations Convention on The Law of The Sea. As an archipelago,

As an archipelago, the government aspires to make Indonesia the world's maritime axis country. This goal
Indonesia has the right to manage (jurisdiction) over the Exclusive Economic Zone.

As an archipelagic country, Indonesia is one of the countries that has benefited from the existence of UNCLOS. The establishment of the Indonesian Exclusive Economic Zone reaches a distance of 200 nautical miles, measured from the Indonesian baseline to the high seas. This decree was later confirmed by Act Number 5 of 1983 concerning the Indonesian Exclusive Economic Zone. The consequence of the implementation of Law Number 5 of 1983 is that the area of Indonesia's marine waters has increased by about 2.7 million $\mathrm{km} 2$ to 5.8 million $\mathrm{km} 2$.

Indonesia has established the Indonesian Archipelago Sea Channel which is used as a benchmark for international shipping routes or foreign ships crossing Indonesian territorial waters. As an archipelagic country, it shows that Indonesia's marine potential is a major market place for foreign countries not only for trade but also for cross-shipping.

will be realized with the support of a strong national shipping industry. The application of the Cabotage Principle in shipping transportation is one of the 
supporting factors for empowering the shipping industry in Indonesia.

The implementation of the Cabotage Principle in the shipping sector was initially regulated in Presidential Instruction Number 5 of 2005 concerning Empowerment of the National Shipping Industry. Furthermore, it is regulated in Article 8 of Law Number 17 of 2008 concerning Shipping, which stipulates that domestic sea transportation activities are carried out by national sea transportation companies using Indonesian-flagged vessels and manned by Indonesian crew members. Foreign ships are prohibited from transporting passengers and/or goods between islands or between ports in Indonesian seas and waters.

The aspiration to turn Indonesia into a world maritime axis is emphasized in the vision and mission of the National Long-Term Development Plan for 20052025. Efforts to realize the country's goals are carried out through a gradual, planned, integrated and sustainable process. Act Number 17 of 2007 concerning the National Long-Term Development Plan 2005-2025 stipulates that the vision of national development is to create an Indonesia that is Independent, Advanced, Just and Prosperous.

Vision 7th of the 2005-2025 Long-Term National Development Plan emphasizes that within 20 (twenty) years of implementation of development in Indonesia, one of them is aimed at realizing the strength and independence of Indonesia as an archipelago.

The policy of implementing the Cabotage Principle on national shipping is a form of state sovereignty and mandatory that must be defended in the national interest. Accelerating marine development is a challenge that must be pursued for the welfare of all Indonesian people. In order to make Indonesia the world's maritime axis, the challenges faced include strengthening the enforcement of national sovereignty and jurisdiction.

Violation of the Cabotage Principle must be subject to strict sanctions because it is a betrayal of the constitution and the Indonesian Shipping Law. As there is still the use of foreign ships in shipping between ports in Indonesia. As in the Kalija 1 project for the installation of an underwater pipeline transmission from the island of Kalimantan to the island of Java, which should have been carried out by Indonesian-flagged vessels but was carried out by foreign vessels, Malaysian-flagged vessels that entered Indonesian waters before the project commenced. Even though the Indonesian-flagged national ship is able to carry out the project.[2]

Such conditions should be prevented by the consistent application of the Cabotage Principle on national shipping transportation.

The development of Indonesia's marine potential and the empowerment of the shipping industry by applying the Cabotage Principle to sea transportation to support Indonesia to become the world's maritime axis are the main focus in this scientific article.

\section{PROBLEMS}

First, how to regulate the application of the Cabotage Principle in sea transportation in Indonesia.

Second, what are the provisions regarding state sovereign rights in the application of the Cabotage Principle on sea transportation to support the empowerment of the national shipping industry.

\section{RESEARCH METHOD}

Based on the problems formulated in this article, a research method with the type of normative legal research is carried out. Normative legal research is intended to study and analyze legal norms that have been established to regulate certain things.

The approach method used is through the statute approach, namely the approach method used to study and analyze all laws, regulations and relevant reading sources. Research on legal principles, legal sources, laws and regulations relating to the application of the Cabotage Principle to sea transportation in Indonesia. The data collection technique is done through literature study or Library research.

\section{DISCUSSION}

First, the application of the Cabotage Principle in sea transportation in Indonesia.

Becoming the world's maritime axis is the goal of the Indonesian government that has long been wanting to be realized. This is supported by Indonesia's position as an archipelago country. Various attempts have been made by the Indonesian government to become the world's maritime axis. Empowering the national shipping industry is one of the efforts and at the same time upholding the country's sovereignty in the maritime sector.

One of the efforts made by the government to develop and empower the national shipping industry is the application of the Cabotage Principle in the implementation of Indonesian sea transportation.

The word Cabotage, in French is Caboter which means to navigate from end to end, or to navigate along the coast. Initially, it was pronounced Capotage. The word comes from the Spanish Cabotaje which means supervised nearshore navigation.

According to Black's Law Dictionary, the definition of Cabotage is: (1) the carrying on of trade along a country's coast; the transport of goods or passengers from one port or place to another in the same country. The privilege to carry on this trade is usually limited to vessels flying the flag of that country. (2) The privilege of carrying traffic between two ports in the same country. (3) The right of a foreign airline to carry passengers and cargo between airports in the same country". [3]

According to Mochtar Kusumaatmadja the Cabotage Principle is defined as a principle or principle which states that shipping activities within the territorial waters of a country can only be carried out by ships from the country concerned. This principle provides the strength 
that the implementation of domestic shipping is fully the right of the coastal state. This means that the coastal state has the right to prohibit foreign ships from sailing and trading along the country's waters. [4]

The Cabotage principle is a principle that is recognized in the law and practice of shipping throughout the world and is an embodiment of a country's sovereignty to manage itself, in this case domestic transportation (land, sea and air), so that it cannot simply be considered as protection, namely protection or unreasonable preferential treatment for domestic companies, resulting in unfair competition. [5]

Cabotage principle is the granting of special rights to ships with the flag of the country concerned for the transportation of goods and people who will sail from and between ports in the country concerned so that the ship is owned or operated by a citizen or business entity established under the laws of that country and concerned.

Indonesia is not the only country that has implemented the Cabotage Principle, but several other countries have already implemented the Cabotage Principle in the implementation of sea transportation, such as the United States, Brazil, Canada, Japan, India, China, Australia, and the Philippines.

The application of the Cabotage Principle in national shipping is part of the sovereignty of the Indonesian state to regulate its own economic activities, with the aim of realizing an efficient and effective sea transportation system and to support economic growth, regional development and strengthen the country's sovereignty. The implementation of Cabotage Principle can improve the economy of the Indonesian people, by providing the widest possible business opportunity for national sea transportation companies. The application of this principle to shipping transportation can increase the activity and productivity of the national shipping company.

The application of the Cabotage Principle is a privilege given to national shipping companies to carry out cargo and passenger sea transportation activities. The Cabotage principle is also a form of state sovereignty and an exclusive right for the state to regulate shipping traffic in accordance with its maritime territorial boundaries with its own statutory regulations.

Legal certainty regarding the policy of implementing the Cabotage Principle on sea transportation in Indonesia is regulated by Presidential Instruction Number 5 of 2005 concerning Empowerment of the Shipping Industry. In this Presidential Instruction, for the first time the government has consistently implemented the Cabotage Principle.

The implementation of the Cabotage Principle was then strengthened by the inclusion of this principle in Act Number 17 of 2008 concerning Shipping.

The Cabotage Principle is domestic transportation activity carried out by national sea transportation companies using Indonesian-flagged vessels and operated by Indonesian crews.

The application of this principle aims to protect the sovereignty of the country and support the realization of the archipelago as well as to provide the widest possible business opportunity for national sea transportation companies. Until now, the implementation of the Cabotage Principle has been going on for fifteen years. In its implementation, Presidential Instruction No. 5 of 2005 has a positive impact on the progress of the national shipping industry.

The application of the Cabotage Principle has been proven to stimulate the national shipping industry and have a major impact on the national economy. Data from the Ministry of Transportation shows that the total ownership of Indonesian flagged vessels in February 2014 was 13,244 units, while in May 2005 the number only reached 6,041 units. This means that there was a significant increase of 7,203 units. An increase of about $119 \%$. This has had a positive impact on the capacity of the number of vessels with the red and white flag, which reached 19.2 million Gross Tonnage or grew 238\% compared to 2005 which was recorded at only 5.67 million Gross Tonnage. [6]

The increase in the number of ships was largely due to the transfer of the flags of ships belonging to national sea transportation companies from foreign flags to Indonesian flags, as well as the construction of new vessels and procurement of used vessels from abroad.

Second, the Sovereign Rights of the State in the Application of Cabotage Principles in Sea Transportation.

The Unitary State of the Republic of Indonesia as an archipelagic country characterized by an archipelago has sovereignty over its territory to be managed and utilized maximally for the welfare and prosperity of the Indonesian people as mandated in the 1945 Constitution of the Republic of Indonesia.

The manifestation of state sovereignty over the sea area is not the same as the manifestation of state sovereignty over the land and air dimensions. Because if the airspace has been traced, until now no one has been able to explain to what extent the airspace lies its final boundary. So far, science is controlled by mankind, when talking about airspace, it is still unknown to what extent the limits of the air column are. That is why until now, the countries on the surface of the earth have yet to agree on the extent to which the airspace of a country's sovereignty will apply. It is different from the embodiment of sea territorial sovereignty, because in understanding the concept of sea area sovereignty, we must first understand the concept of sovereignty itself.

According to Priyatna Abdurrasyid, the territory of the Republic of Indonesia consists of one-third of land, two-thirds of water and three-thirds of air.[7]

In such a composition, attention to the territorial waters, especially the oceans, as an area of state sovereignty, naturally deserves proportional priority. On the other hand, the territory of a state's sovereignty over the ocean territory, in the view of "national security" and at the same time in the context of the economy or "national prosperity" is clearly visible in the course of world history and in the history of the Indonesian nation.

The definition of sovereign rights according to the 
Big Dictionary of Indonesian is the right that has the highest power over a state or regional government. [8]

The definition of Sovereign Rights according to Article 56 paragraph 1 (a) of the United Nations Convention on the Law of the Sea 1982 is the right that has the highest power over the needs of exploration and exploitation, conservation and management of natural resources, both living and non-living, from the waters above the seabed and the land beneath it.

According to Hikmahanto Juwana: the state's sovereign rights over the sea area are the rights owned by the coastal state to utilize natural resources in the Exclusive Economic Zone and the Continental Shelf. [9] Indonesia's sovereign rights over the sea area means that Indonesia has the right to exploit all potential natural resources in the Exclusive Economic Zone and continental shelf areas.

The meaning of state sovereign rights over water territories requires further understanding. This is because the sea zones owned and controlled by a country can be differentiated based on sovereign rights and sovereign rights of the state in the sea area.

State sovereignty over its territory has two aspects. Positive aspects and negative aspects. The positive aspect of the state's territory is in the form of the highest power or exclusive authority of the state over its territory. Meanwhile, the negative aspect is that outside of its territory a country no longer has such power because that power ends and the power of another country begins. The negative aspects of the country's territory are indicated by the state's obligation to protect the rights of other countries in its territory.

Sovereignty or sovereign is the highest necessity in a country that cannot be divided. [10] The understanding of the sovereignty of a country is often limited to the scope of the sovereignty of a country which is limited by the territorial borders of a country with other countries, meaning that a country only has sovereignty in accordance with its territorial boundaries that have been recognized by other countries, because outside the territory of a country already exists. Power and sovereignty of other countries over their territory. This has become an internationally understandable matter that every country has sovereignty over its territory which consists of land space, ocean space and waters and air space in a country.

The sovereign rights of the Republic of Indonesia over the sea and territorial waters of Indonesia are stipulated in the form of statutory regulations. This provision is contained in Act Number 5 of 1983 concerning Indonesia's Exclusive Economic Zone.

The preamble section number (5) states that the marine environment in waters under and the jurisdiction of the Republic of Indonesia must be protected and preserved. Furthermore, Article 4 (a) of Act Number 5 Year 1983 stipulates that, in the Indonesian Exclusive Economic Zone, the Republic of Indonesia has and exercises sovereign rights to explore and exploit, manage and conserve living and non-living natural resources from the basis of sea and land beneath it and water above it and other activities for exploration and economic exploitation of the zone, such as hydroelectric power, electric currents and wind direction.

In principle, every country has full sovereignty over its territory, whether land, sea or air, where the applicable law is the national law of each country. The boundaries of a country have been regulated based on an agreement made by 2 (two) or more countries whose territories are close together. [11]

Consequent application of the Cabotage Principle in national shipping can be seen in the firm actions taken by the government in the implementation of the Kalija 1 Project.

The Kalija I project (2014-2015) is a national project for the construction of an undersea and onshore natural gas pipeline to connect the Kepodang gas field off the coast of the Java Sea to the PLN power plant at Tambak Lorok, Semarang, Central Java. The project is known to use the Sapura Kencana 900 type derrick \& pipe laying barge with the Malaysian flag.[12]

The use of foreign ships in Indonesia is regulated in the Minister of Transportation Regulation No. 10 of 2015 concerning the second amendment to the Regulation of the Minister of Transportation No. 10 of 2014 concerning Procedures for Requirements for Granting Permits to Use Foreign Ships for other activities that do not include transporting passengers and/or goods in domestic sea transportation activities.

Article 1 paragraph 1 of the Regulation of the Minister of Transportation No. 10 of 2015 states that foreign ships can carry out other activities that do not include activities of carrying passengers and/or goods in domestic sea transportation activities in Indonesian waters as long as Indonesian-flagged vessels are not yet available or not sufficiently available.

In fact, Indonesian-flagged vessels exist and are able to carry out the shipping required for the Kalija I Project. So this is a violation of Article 8 of Law Number 17 of 2008.

The government through the Ministry of Transportation does not tolerate and takes firm action against parties who violate the application of the Cabotage Principle by using foreign ships without permission from the government through development projects in Indonesia by giving a subpoena in the form of temporarily suspending the implementation of the Kalija I Project and the implementing party. the project must use a national ship for the project by ordering foreign vessels with Malaysian flags to immediately stop their work and return to their country within 30 (thirty) days after the summons. The Kalija I project can resume operations after the subpoena is executed.

Sanctions for violating Article 8 are regulated in Article 284 of Law Number 17 of 2008 concerning Shipping. Every person who operates a foreign ship to transport passengers and/or goods between islands or between ports in Indonesian waters, shall be punished with a maximum imprisonment of 5 (five) years and a maximum fine of Rp. 600.000.000. (Six Hundred Million Rupiah). 
The basic concept of the space for the exercise of sovereignty as the highest state power is limited by the territory of the state, so that the state has the highest power within its territorial boundaries. Without certain territories and boundaries, a country cannot be considered a subject of international law.

The definition of a state here cannot be separated from the concept of a state as a geographical unit accompanied by its respective sovereignty and jurisdiction. Thus, the territory of the state becomes the most fundamental concept (fundamental) in international law, to show the existence of the highest power.

Sovereignty is full authority over the territory, which in this case includes all land areas, archipelagic waters and territorial seas and what applies to these areas is the national law of a country.

Sovereign rights are the rights to manage and utilize for the purposes of exploration and exploitation, conservation and management of both living and nonliving natural resources from the waters above the seabed and from the seabed and the land beneath them and in relation to other activities for the exploration and exploitation needs of the economic zone, such as energy production from water, currents and wind. The area where the sovereign rights of the state are exercised is known as jurisdiction.

The state has jurisdiction, right or authority to determine applicable laws in its sovereign territory. Apart from the area of sovereignty, there are also areas that are not under state sovereignty known as terra nulius. There are areas that cannot be subordinated to the sovereignty of any country called res Communis, such as the high seas, the international seabed area and outer space. [13]

Regarding the application of the Cabotage Principle as the embodiment of state sovereignty and applying this principle to the territory of the country's sovereign rights in sea transportation, the Indonesian Government issued Presidential Instruction Number 5 of 2005 concerning the Empowerment of the National Shipping Industry which regulates the enforcement of the Cabotage principle on the sovereignty of Indonesia's marine territories. In order to accelerate the implementation of Presidential Instruction Number 5 of 2005, the government has formulated follow-up plans including accelerating the completion and enactment of regulations as the implementation of Presidential Instruction Number 5 of 2005, facilitating and continuing to encourage the banking sector and other non-bank financial institutions in supporting the provision of loans/credits for fleet development. national commerce, improve coordination with the Ministry of Finance to provide incentives in the field of taxation in supporting the empowerment of the national shipping industry, establish and enforce regulatory provisions requiring national shipping companies to insure ships, cargo/goods, encouraging Indonesian National Shipowners' Associations (INSA) to consolidate with its members to form a consortium for similar sea transportation companies to replace foreign ships that dominate certain commodities in logistics shipping in Indonesia.

The Cabotage Principle is regulated in Presidential Instruction Number 5 of 2005 and Law Number 17 of 2008 Concerning Shipping.

Presidential Instruction Number 5 of 2005 is a government policy supported by business actors and has made the national shipping industry continue to experience rapid growth to date. The Cabotage Principle Policy has been successful in safeguarding the country's sovereignty from the security and defense aspects while at the same time encouraging national economic growth.

According to Carmelita Hartoto: since the enactment of Presidential Instruction No. 5 of 2005, investment in the shipping sector and other related industries has continued to increase until now. The number of national vessels has increased. In 2005 there were only 6,041 units. In 2016 there were 24,046 units. This fleet consists of shipping sea transportation and special sea transportation. Total transport capacity has increased from 5.67 million GT in 2005 to 38.5 million GT in 2016. Amount of national shipping company growth has also increased.[14]

According to Budhi Halim: with a large enough strength, national shipping has also been able to serve all domestic cargo distribution. In 2016, all domestic cargo distribution has been served by national ships from a total cargo of 621 million tons in 2016.[15]

The application of the Cabotage Principle has succeeded in increasing the competitiveness of the national shipping industry. The following are some of the impacts of implementing the cabotage principle in Indonesia: (1) Amount of vessels increased by $132 \%$ from 6,041 vessels in 2005 to 14,036 in 2014; (2) The total capacity of the fleet increased by $351 \%$ from 3.66 million DWT in 2005 to 12.88 million DWT in 2013; (3) Since the implementation of the cabotage principle, the number of shipping companies has increased by 2,866 ; the number of companies supplying maritime equipment increased by 51 companies; shipping service companies increased by 1,894 companies; and shipbuilding companies increased by 250 companies; (4) In 2005 , Indonesia's shipping fleet capacity was ranked 4 th in Asean, below Malaysia and the Philippines, while in 2013 Indonesia's shipping fleet capacity was ranked 2nd ahead of Malaysia and the Philippines.[16]

The Implementation of the Cabotage Principle to sea transportation has had a positive impact on the national shipping industry. This is evident from the data on the increase in the number of Indonesian-flagged vessels and the increase in national logistics shipping activities. The increase in the number of Indonesian-flagged vessels has further strengthened the empowerment of the national shipping industry which is also one of the factors supporting the acceleration of the realization of Indonesia to become the world's maritime axis.

\section{CONCLUSION}

First, the application of the Cabotage Principle in sea transportation in Indonesia is regulated in Presidential Instruction No. 5 of 2005 concerning Empowerment of 
the National Shipping Industry. This government policy is supported by business actors in the shipping sector and is able to increase the growth and empowerment of the national shipping industry. The implementation of the Cabotage Principle is then strengthened by the regulation of this principle in Article 8 of Law Number 17 of 2008 concerning Shipping.

Second, the application of the Cabotage Principle aims to protect the country's sovereignty and support the realization of the archipelago's insight and provide the widest possible business opportunity for national sea transportation companies. The urgency of implementing the Cabotage principle in sea transportation in Indonesia is based on the idea that domestic marine transportation has a strategic and significant role in national development, starting from the economic, social, cultural, political, defense and security sectors. So that the potential that exists in national shipping must be empowered to make Indonesia an independent and advanced maritime country, while at the same time supporting Indonesia to become the world's maritime axis.

\section{ACKNOWLEDGMENTS}

This research was carried out because of the help of many parties. Therefore, we would like to thank all those who have helped, including: Lembaga Penelitian Universitas Sumatera Utara for funding this research in accordance with the TALENTA Research Implementation Contract, Universitas Sumatera Utara for Fiscal Year 2018 Number: 2590/UN5.1R/PPM/2018 March 16, 2018.

\section{REFERENCES}

[1] https://kkp.go.id/djprl/artikel/21045-konservasiperairan-sebagai-upaya-menjaga-potensi-kelautandan-perikanan indonesia\#: :text=Indonesia\%20merupakan\%20negar a\%20kepulauan \%20terbesar,km2\%20adalah\%20Zona $\%$ 20Ekonomi\%20Eksklusif. (data obtained from the website of the Directorate General of Marine Spatial Management which was uploaded on 01 July 2020 and accessed on 05 November 2020)

[2] Mabrori. Akhmad, Editor: Yusuf Waluyo Jati, Pakar: Para Pelanggar Asas Cabotage Khianati Konstitusi, Bisnis.com,

https://ekonomi.bisnis.com/read/20150419/98/424540/p akar-para-pelanggar-asas-cabotage-khianati-konstitusi published on: 19 April 2015, Accessed on: 8 Desember 2021.

[3] Umar, M. Husseyn. 2001. Hukum Maritim dan MasalahMasalah Pelayaran di Indonesia, Pustaka Sinar Harapan: Jakarta. pg. 138.

[4] Kusumaatmadja, Mochtar. 1994. Pelayaran Nasional dalam Rangka Penegakan Wawasan Nusantara, Kanindo: Jakarta. pg. 7.

[5] Siregar, Mahmul. et.al. 2012. "Cabotage Principle
Pada Regulasi Jasa Angkutan di Dalam Perairan Indonesia dari Perspektif Sistem Perdagangan Multilateral WTO/GATS", USU Law Review, Volume XII, No. 2, November, Universitas Sumatera Utara: Medan.

[6] Rahmat, Novy. 2015. Mengingat (Lagi) Asas Cabotage, Marine Claim Manager at PT. KBRU Insurance Broker, https://id.linkedin.com/pulse/mengingat-lagi-asascabotage-novy-rachmat Published on June 18, 2015. Accessed on: 07 April 2018

[7] Abdurrasyid, Priyatna. 1972. Kedaulatan Negara di Ruang Udara, Pusat Penelitian Hukum Angkasa: Jakarta. pg. 26.

[8] Kusumaatmadja, Mochtar. 1982. Pengantar Hukum Internasional, Buku I - Bagian Umum, Bina Cipta: Bandung. pg. 15.

[9] Wirawan, Jerome. BBC News, 22 Juni 2016, https://www.bbc.com/indonesia/berita indonesia/ 2016/06/160621_indonesia_natuna_cina_indones ia Accessed on: 3 Januari 2017.

[10] Sulaiman, King Faisal. 2013. Sistem Bikameral dalam Spektrum Lembaga Parlemen di Indonesia, UII Press: Yogyakarta. pg. 17.

[11] Hasjimzum, Yusnani. 2014. "Perlindungan Hukum Negara Terhadap Kedaulatan Wilayah Laut", Jurnal Monograf, Jakarta. Volume 2. pg. 194Mabrori. Akhmad, Editor: Yusuf Waluyo Jati, Pakar: Para Pelanggar Asas Cabotage Khianati Konstitusi, Bisnis.com, https://ekonomi.bisnis.com/read/20150419/98/424 540/pakar-para-pelanggar-asas-cabotage-khianatikonstitusi published on: 19 April 2015, Accessed on: 8 Desember 2021.

[12] Mochtar, Kusumaatmadja dan Etty Agoes. 2003 Pengantar Hukum Internasional, Alumni: Bandung. pg. 165.

[13] Asas Cabotage demi Kedaulatan Negara, Published on: 22 September 2017. https://insa.or.id/asas-cabotage-demi-kedaulatannegara/ Accessed on: 12 Juli 2019.

[14] Asas Cabotage demi Kedaulatan Negara, Published on: 22 September 2017. https://insa.or.id/asas-cabotage-demi-kedaulatannegara/ Accessed on: 12 Juli 2019.

[15] Haryana, Avif. 2018. Cabotage dan Beyond Cabotage: Upaya Mendongkrak Performa Industri Pelayaran Nasional, dalam "Warta Pengkajian Perdagangan", Volume I. No. 15, Agustus. $\quad$ pg. 32 https://www.researchgate.net/publication/327306 976_Cabotage dan_Beyond_Cabotage Upaya Mendongkrak_Performa_Industri_Pelayaran_Nas ional\#fullTextFileContent Accessed on: 8 November 2020. 